\title{
DEVERES INTERGERACIONAIS: COMO DEFINI-LOS A PARTIR DA FILOSOFIA?
}

\author{
Geraldo Alves Teixeira Júnior ${ }^{2}$ \\ Marijane Vieira Lisboa ${ }^{3}$
}

\begin{abstract}
Resumo: Conhecer os deveres que temos em relação às geraçóes futuras é cada vez mais urgente, diante da degradação individual, social e ambiental que a humanidade enfrenta. O presente artigo pretende mostrar, de início, a complexidade filosófica dessa questăo, indicando que, nos enunciados sobre o assunto, há três pressuposiçōes filosoficamente problemáticas: 1) haverá geraçōes futuras; 2) nossas açōes são contingentes; e 3) somos responsáveis por nossos impactos sobre as próximas geraçôes. Discutimos essas suposiçóes, por meio das questóes sobre a eternidade do mundo, a existência da liberdade e o significado de dever, e abordamos, em seguida, as ideias convergentes de Hans Jonas e Ulrich Beck, as quais apontam que a singularidade do poder que a tecnologia conferiu ao ser humano requer agora um novo pensamento ético. $\mathrm{Na}$ conclusão, argumentamos que é preciso definir deveres em relação às geraçóes futuras e elencamos quais seriam, a nosso ver, os principais deles, levando em conta a ideia de incerteza, alcançada tanto por meio das discussóes filosóficas apresentadas quanto a partir da nova conjuntura tecnocientífica de nosso tempo.
\end{abstract}

Palavras-chave: Futuro. Incerteza. Tecnologia. Ética intergeracional. Dever intergeracional.

\section{INTRODUÇÃo}

As discussôes acerca dos deveres intergeracionais são cada vez mais fre-

\footnotetext{
${ }^{1}$ http://dx.doi.org/10.1590/S0101-31732018000100003

${ }^{2}$ Unicamp, Campinas, SP - Brasil. E-mail:gatjr@uol.com.br.
}

Graduado em Relaçôes Internacionais pela PUC-SP, Doutor em Filosofia pela Unicamp. Realizou pós-doutorado como bolsista do programa PNPD/Capes na UFG entre 2013 e 2016, período no qual esse artigo foi produzido. Principais trabalhos e publicaçôes na área de Ética e Filosofia Política, e nas interseçôes desta com os outros campos das humanidades. Autor do livro A política antiterrorismo dos Estados Unidos: de onde e para onde? (Luminária, 2015).

${ }^{3}$ Professora da Faculdade de Ciências Sociais da PUC-SP para os cursos de Relaçóes Internacionais e Ciências Sociais, São Paulo, SP - Brasil. E-mail: marijane.lisboa@gmail.com

Doutora em Ciências Sociais, foi Relatora de Direito Humano Ambiental da Plataforma DHESCA, por dois mandatos, de 2007-2011, e Secretária de Qualidade Ambiental nos Assentamentos Humanos do Ministério do Meio Ambiente, entre 2003 e 2004. Foi membro titular da Comissão Técnica Nacional de Biossegurança, CTNBio, por dois mandatos, entre 2012 e 2016. É autora do livro Ética e cidadania planetárias na era tecnológica (Civilização Brasileira, 2009). 
quentes. No campo das ciências humanas elas surgem, sobretudo, a partir da sociologia e do direito (MEYER, 2010), em torno dos debates ambientais desenvolvidos por essas disciplinas. Na filosofia, o tema também encontra repercussão e, na maioria das vezes, aparece relacionado às discussões da Ética contemporânea. Ao abordar aqui esse problema, partimos de um entendimento de que, independente da perspectiva que orienta a análise, uma boa abordagem deve partir do reconhecimento de que a questão sobre os deveres que temos em relação às geraçóes futuras é um problema complexo. Complexo, em primeiro lugar, no sentido comum do termo, o qual expressa sua dificuldade e a necessidade de que o tema seja abordado pelas diversas áreas do conhecimento. Não se pode dizer que esse reconhecimento tem estado ausente das discussóes. A seguir, pretendemos indicar, porém, que o tema é complexo também em outro sentido, que, embora seja bastante relevante para aprofundar o modo como pensamos um comportamento humano adequado para os tempos atuais, ainda é, a nosso ver, pouco discutido. $\mathrm{O}$ sentido ausente da complexidade dos deveres intergeracionais refere-se ao significado mais propriamente filosófico do termo:

Os estoicos, que introduziram esse termo, entenderam por ele as proposiçóes compostas, isto é, constituídas ou por uma só proposição tomada duas vezes (p.ex.: "se é dia, é dia”), ou por proposições diferentes unidas por um ou mais conectivos (p.ex.: "É dia e há luz", “Se há dia, há luz", etc.). (ABBAGNANO, 2007, p. 156).

Ao afirmar a complexidade da questão, portanto, buscamos apontar as partes de um enunciado geral, e entendemos que qualquer afirmação sobre os nossos deveres intergeracionais é composta de várias proposiçôes relacionadas. Ou seja, na proposição "nossos deveres em relação às geraçôes futuras são...", podemos encontrar ao menos três proposiçóes implícitas, ou pressuposiçóes, que orientam a resposta independentemente de como a frase venha a ser completada: 1) haverá geraçóes futuras; 2) os impactos que geramos sobre elas são contingentes e; 3) somos responsáveis por esses impactos. Ao longo das três primeiras seções, a reflexão abaixo buscará problematizar e mostrar a plausibilidade de cada uma dessas afirmaçóes.

A última proposição, a de que somos responsáveis pelos impactos que causaremos às geraçóes futuras, leva-nos a uma investigação acerca desses impactos, pois, se sua magnitude fosse ínfima, nossa responsabilidade de controlá-los em prol das geraçóes futuras seria igualmente insignificante. Por isso, argumentamos, na quarta seção, que o uso atual dos recursos técnicos e 
tecnológicos ampliam os efeitos que produzimos e interferem no futuro do planeta e das geraçóes humanas, de modo significativo. Pretende-se ainda, nessa passagem, apontar como essa ampliação do poder humano gera também a necessidade de se considerar novos deveres capazes de equilibrá-los e, portanto, a necessidade de se pensar novas questóes éticas que não haviam sido colocadas em contextos anteriores.

\section{HaVERÁ geraÇóES FUTURAS}

A existência de geraçóes futuras parece ser uma verdade histórica evidente. Baseia-se na experiência passada de toda a humanidade e na simples continuidade biológica da espécie. Fundamenta-se ainda na expectativa de duração temporal das construçôes presentes e cotidianas, isto é, na expectativa de perpetuação desses artifícios materiais - como as ferramentas, os edifícios, as cidades - e imateriais - como as leis, a ciência, a arte, a cultura - com os quais os indivíduos, de forma particular, e a humanidade, em geral, buscam assegurar sua preservação no ambiente natural e social.

A essa certeza histórica opóe-se um fatalismo filosófico arcaico - isto é, inicial e relacionado aos princípios do pensamento filosófico - perceptível tanto na cultura oriental quanto na tradição ocidental. Não são poucas as referências nos campos da Física, da Metafísica e da Política que concluem, embora com argumentos distintos e partindo de ontologias diversas, que nada que um dia surgiu poderá durar.

Por volta do século VI a.C., a já então antiga filosofia do Yin e Yang ganhava forma textual no Tao te King de Lao-Tsé. Ali, o ser e o não-ser opóem-se na Unidade misteriosa e indizível do Tao (LAO-TSÉ, 2007, XIV, p.30). Os opostos se equilibram e, ao fazê-lo, possibilitam a continuidade das coisas, mas tornam tudo temporário, desde as vidas menores - "tudo o que floresceu e se multiplicou, à sua raiz voltará” (LAO-TSÉ, 2007, XVI, p. 32) - até o próprio cosmos, o qual, tendo surgido do nada, encontra aí também o seu destino:

Antes que existissem o Céu e a Terra, havia um algo perfeito e igual, silencioso e impassível. / Permanece único e imutável, se move por onde quer. / Poderíamos chamá-lo de a Mãe de todas as coisas. / Como não conheço o seu nome o chamo Tao. / Como não posso lhe dar seu verdadeiro nome o chamo Grande./ Grande significa que está em eterno movimento; eterno 
movimento significa que se distancia; distanciar-se significa que retorna. (LAO-TSÉ, 2007, XXV, p. 38-39).

No dualismo platônico entre mundo sensível e inteligível, encontramos a fatal degeneração das coisas contraposta à eternidade das ideias. Aquilo que está no campo do sensível não pode possuir toda a perfeição que o faça durar, pois tudo o que algum dia surgiu é, de algum modo, cópia do perfeito e eterno, e, por isso, imperfeito e transitório, como se constata na passagem sobre a criação do mundo sensível pelo demiurgo:

Como acontece que este é um ser eterno, tentou, na medida do possível, tornar o mundo também ele eterno. Mas acontecia que a natureza daquele ser era eterna, e não era possível ajustá-la por completo ao ser gerado. Então, pensou em construir uma imagem móvel da eternidade, e, quando ordenou o céu, construiu, a partir da eternidade que permanece uma unidade, uma imagem eterna que avança de acordo com o número; é aquilo a que chamamos tempo. Todos eles são partes do tempo [...]. (PLATÃO, Timeu, 37d-e).

Nesse quadro, ao que foi criado cabe o passado e o futuro, pois o presente eterno pertence apenas ao criador (PLATÃO, Timeu, 37e-38a). As criaturas estão sujeitas ao tempo e às mudanças, que é o princípio do fim das coisas. O nascer indica já um fim necessário, seja do homem, seja de suas obras. Na República, por exemplo, discute-se como formas corruptas de governo poderiam surgir em uma cidade bem construída e conduzida. Sócrates diz a Glauco que, quando chamadas a dizer "como surgiu a discórdia pela primeira vez", as Musas "se exprimiriam no estilo nobre da tragédia", respondendo: «É difícil que uma cidade constituída como a vossa venha a rebelar-se; mas, como tudo o que nasce está sujeito à corrupção, este sistema de governo não durará eternamente, mas se dissolverá [...].” (PLATÃO, República, VIII, 546a).

A separação entre um mundo superior eterno e a mutabilidade decadente do mundo terreno é fundamental também no pensamento cristão e está presente na distinção entre temporal e espiritual, que perpassa sua teologia. Para Deus, náo há tempo, pois é Ele quem o cria a partir de sua vontade eterna e imutável (AGOSTINHO, 1980, XI, p. 10):

Vós, pelo contrário, permaneceis sempre o mesmo, e os vossos anos náo morrem". Os vossos anos não vão nem vêm. Porém os nossos vão e vêm, para que todos venham [...]. Quanto aos nossos anos, só poderão existir todos, quando já todos não existirem. Os vossos anos são como um só dia, e o vosso dia não se repete de modo que possa chamar-se cotidiano, mas é um perpétuo "hoje" [...]. O vosso "hoje" é a eternidade. Por isso gerastes 
coeterno o vosso Filho, a quem dissestes: "Eu hoje te gerei". (AGOSTINHO, 1980, XI, p. 13).

Nesse pensamento fundamental à tradição cristá, a ordem do temporal é uma percepção que temos da eternidade, porque nossa perspectiva é aquela das criaturas mutáveis, sujeitas aos séculos. Dividir o tempo em passado, presente e futuro, porém, nada mais é que um recurso que usamos em nossa condição corpórea e temporal (AGOSTINHO, 1980, XI, p. 20).

Se o tempo foi criado, se ele surgiu, terá também um fim, pois se transformou e, por não ser imutável, tampouco pode ser eterno. O tempo e as coisas, portanto, fatalmente deixarão de ser, e sua duração está marcada por um evento final que levará ao fim dos tempos. A expectativa de um último presente, após o qual cada um seria julgado e destinado a passar a eternidade no paraíso ou no sofrimento e infortúnio, marca o pensamento cristáo até nossos dias. A interpretação sobre o último dia, porém, modificou-se segundo os momentos históricos e, embora esse evento pareça mais uma metáfora bíblica ou algo indeterminadamente distante, ele era esperado ansiosamente por aqueles que viveram durante a Alta Idade Média. Trata-se de algo que afetou o imaginário dos povos europeus, influenciando profundamente não apenas a açáo individual, mas a ordem social, o domínio político e o modo de pensar.

As desordens políticas resultantes da queda do Império Romano, assim como o avanço do islamismo, impulsionavam a expectativa de que a chegada do ano 1000 traria também o fim dos tempos. Vale lembrar que a teologia agostiniana, a qual definiu no cristianismo a transmissibilidade do pecado original e a consequente natureza impura do ser humano, reinou hegemônica durante esse período. Parece compreensível, portanto, que, ao ser unida a ideia do juízo final à da condição pecadora do ser humano e à expectativa do fim próximo, a salvação das almas emergisse como o que havia de mais urgente. Assim, no período em questão, o chamado agostinismo político subordina o poder do governante ao objetivo da salvação, fazendo do rei um "ministro de Deus" e, simultaneamente, sustenta a estrutura hierárquica da sociedade e o modo como a política é conduzida e pensada: $\mathrm{Na}$ ótica de uma "história do governo", é mais exato dizer que as finalidades governamentais, espiritual (salvação das almas) e temporal (disciplina dos corpos), condicionam a ética do Estado. Em vez de negação do político, é a finalização da força que constitui o caráter original desse período (SENELLART, 2006, I, 1, p.41).

Apenas com a passagem do século XI, o milenarismo começa a perder força, liberando o governo de sua função escatológica. O processo de 
secularização é longo e tem como fatores de maior relevância a redescoberta dos textos éticos e políticos de Aristóteles e sua interpretação por Tomás de Aquino. Para o nosso propósito, é importante realçar que essa mudança quanto à expectativa de futuro, doravante com duração indefinida, alterou mais uma vez o fazer e o pensar a ética e a política. O alívio do peso de se pensar o fim do mundo como algo tão próximo gerou tanto uma curiosidade acerca do passado quanto uma disposição para a construção de um futuro. Ou seja, o que esse processo marca é a ascensão do transitório, do temporal, como assunto de maior relevância.

No campo da ética, embora ainda longe de abandonar a religião, a filosofia volta-se ao valor do humano, a partir do século XIII. No humanismo, fica claro que a temporalidade do ser humano náo o obriga a fazer do objetivo espiritual da salvação o único fim - mesmo que esse possa ser ainda o fim maior. Retomam-se os valores mundanos da glória e da fama e passa-se a insistir cada vez mais na responsabilidade do indivíduo diante da ordem social, que é construída pela participação, e não pré-determinada em função de uma finalidade a-histórica (SPITZ, 1996; SKINNER, 1999, II, p. 4).

A continuidade do governo, isto é, sua duração no tempo, vai se tornando cada vez mais importante. Como reflexo disso, a Baixa Idade Média vê surgir as doutrinas sobre "os dois corpos do rei". Ernst Kantorowicz aponta que, mesmo previamente à redescoberta dos textos de Aristóteles - que marca uma nova importância das questôes temporais, a partir do século XIII - já existia certo desenvolvimento no sentido da continuidade, nos campos da lei e da política (KANTOROWICZ, VI, 1, p.273). Essa continuidade era reforçada de distintos modos, durante os rituais de sucessão monárquica e por outros meios, como a produção de efígies dos reis. Bredekamp assinala que tais imagens serviam para "restituir a presença" dos soberanos e "[...] transpor do passado para o presente e para o futuro a cadeia mental dos dignitários e compreendê-la como uma figura composta, que foi decomposta pelo tempo." (BREDEKAMP, 2003, V, p. 98).

A partir dos séculos XVI e XVII, a busca por tornar duradouro o poder constituído veio a ser um dos fatores fundamentais a definir o Estado como agente principal da política moderna. Essa duração do poder foi construída no contexto estatal através da criação de funçôes e instituiçóes permanentes de governo. O Estado foi construído para durar e, apesar das ambiçóes absolutistas, seu poder já não dependeria exclusivamente do governante, mas de suas instituiçôes, cujas orientaçôes poderiam ser modificadas, porém, cuja 
existência era ininterrupta.

Como se frisou, não se trata de dizer que a ontologia foi invertida e que a crença no fim do mundo foi substituída pela certeza de sua eternidade. Em uma das mais conhecidas obras artísticas sobre o ser e o não ser, Shakespeare (1978, I, 2, p. 209) retrata a fatalidade das coisas: "Tudo o que vive deve morrer, passando pela natureza em direção à eternidade." Interessa notar que a rainha critica o estado desolado de Hamlet, insistindo na vulgaridade desse fatalismo: "Por que, pois, por perversa oposição à regra, tomar tão a peito o que deve ser e que sabemos tão comum quanto a coisa mais vulgar?" (SHAKESPEARE, 1978, I, 2, p. 209-210).

Essa certeza que temos, com base na experiência, contudo, é incapaz de se tornar regra absoluta, pois nos falta o conhecimento empírico acerca do destino das coisas cuja origem e fim não presenciamos, ou daquelas que precedem todas as demais. Isto é, mesmo que possamos conhecer a relaçáo do tempo com cada coisa particular, ignoramos a relação do tempo com as espécies de coisas, bem como com o universo como um todo. A conclusão sobre o fim de todas as coisas individuais não se estende ao universo, ao mundo, ou mesmo à própria humanidade: ela não alcança, portanto, a origem e o fim absolutos, mas apenas as existências intermediárias.

A questáo sobre a eternidade do mundo, entendido como totalidade dos fenômenos, é apresentada por Kant como algo sobre o que qualquer afirmação ou negação não pode ser conclusiva (KANT, 2001, B454 e seg.). Em última instância, portanto, do ponto de vista filosófico, a existência de um futuro é, ao modo de Hume (1996, IV), uma expectativa que construímos com base em experiências anteriores, mas que jamais pode passar da probabilidade à certeza. $\mathrm{Na}$ verdade, no que diz respeito a tudo o que se encontra na natureza, a tradição filosófica parece conferir muito mais certeza ao fim necessário que à eternidade.

Com o desenvolvimento da ciência contemporânea, a afirmação sobre o destino do mundo é postulada em uma nova linguagem e recorrendo a argumentos derivados de práticas experimentais. A segunda lei da termodinâmica afirma que, em um sistema isolado, a energia tende a se dissipar ou, em termos mais específicos, que a entropia aumenta. Visto que a entropia pode ser concebida como a "[...] tendência estatística da natureza à desordem" (WIENER, 1968, II, p. 28), sob a perspectiva da matéria, essa dissipação é sinônimo de desordem. A noção de sistemas isolados, utilizada no enunciado, possui sem- 
pre valor relativo, podendo significar desde a célula até o universo. Assim, o conceito de entropia auxilia no entendimento de que o mundo, um "sistema isolado" que perde energia para que o universo se aproxime do equilíbrio, caminha rumo ao seu fim inexorável. A dissipação de energia a partir dos sistemas menores gera primeiro o caos no interior de cada sistema isolado e, por meio dos fluxos energéticos originados nas várias unidades, conduz, por fim, a um equilíbrio que resultaria na estabilidade total:

Mais cedo ou mais tarde, morreremos, e é altamente provável que todo o universo à nossa volta morra de morte calórica, morte na qual o mundo se reduzirá a um só e vasto equilíbrio de temperatura, em que nada de realmente novo irá acontecer. Não restará nada a não ser uma insípida uniformidade, da qual só podemos esperar flutuaçóes insignificantes. (WIENER, 1968, II, p. 31).

Todavia se, de fato, todo o percurso é apenas o caminho rumo ao abismo, parece ser inevitável também a questáo sobre qual o propósito de qualquer ação. De que pode servir esse memento mori para a humanidade? Seria isso apenas uma confirmação de que, diante da degradação ambiental, social e individual, devemos fazer da utopia um gênero literário ultrapassado e adotar a destopia como nova visão de futuro? Com efeito, cada vez mais sombrio nos parece um futuro no qual vislumbramos a artificialidade total da vida, imagens de uma natureza totalmente extinta e de pessoas sem capacidade criativa, controladas por códigos numéricos, as quais agem como máquinas pré-programadas para cumprir uma função dentro de um sistema em cujos rumos não podem interferir. Essas imagens parecem-se cada vez mais com um retrato do fim.

Embora a catástrofe final anunciada possa resultar em uma acomodação, ela pode ser também um chamado à ação, caso “[...] a visão de nossos esforços para progredir em face da esmagadora necessidade possa ter o terror catártico da tragédia grega." (WIENER, 1968, II, p. 41). Se, portanto, diante da certeza do fim, nós nos tornamos livres para conhecer nossa própria essência, temos ainda a chance de compreender que a dignidade do ser humano, nessa tendência universal à destruição, está justamente em buscar possibilidades de organizaçóes. Afinal, a consideração de que no mundo, tomado como sistema, a entropia aumenta naturalmente, não implica a desordem absoluta, nem durante todo o tempo, nem em todas as partes: "Há ilhas locais e temporárias de entropia decrescente num mundo em que a entropia tende a aumen- 
tar globalmente, e a existência dessas ilhas possibilita a alguns de nós afirmar a existência de progresso." (WIENER, 1968, II, p. 37).

Nesse sentido, “[...] a perspectiva de uma morte final está longe de constituir uma completa frustração da vida; isso é tão verdadeiro para a civilização e a raça humana quanto para cada um de seus indivíduos componentes." (WIENER, 1968, II, p. 47). Wiener cita Kierkegaard para afirmar que no caos moral em que nos encontramos, nosso principal dever é estabelecer espaços de ordem, os quais, apesar de arbitrários e temporários, não são sem significado e nem injustificáveis.

Pensar nossos deveres em relação às geraçóes futuras, portanto, é, antes de tudo, pensar a própria possibilidade de existência dessas geraçóes. Do ponto de vista moral, nossa incapacidade filosófica e científica de precisar quantas geraçóes ainda haverá, ao invés de isentar-nos de qualquer responsabilidade sobre elas, deveria levar-nos a considerar que são indeterminadas. Ou seja, mesmo sem saber até quando - devido às questôes metafísicas, científicas, sociais e ambientais -, sabemos que haverá geraçôes futuras. Assim, se a ética do indivíduo deve conduzir à felicidade, aquele bem supremo que pode ser atingido por meio da ação humana (ARISTÓTELES, Ética a Nicômaco, I, p. 4), a ação da humanidade em conjunto deve buscar a felicidade da espécie humana. Nessa perspectiva, devemos refletir sobre todos os indivíduos no espaço e no tempo, mas também, como veremos, sobre o próprio ambiente de sua existência. A humildade de nosso conhecimento deve ser complementada, portanto, pela grandeza de um projeto que se pretende válido, não eternamente, mas indefinidamente.

\section{OS IMPACTOS QUE GERAMOS SÁO CONTINGENTES}

Afirmar a contingência dos resultados de nossas açōes é outro problema que instigou a filosofia, ao longo dos séculos. Entender que aquilo que realizo poderia ocorrer de modo distinto do que ocorreu e que, por conseguinte, posso também buscar resultados diferentes para o que ainda virei a realizar, significa supor a liberdade humana. Não obstante possamos, por meio da experiência, afirmar a existência de nossa liberdade, ela parece não poder ser absolutamente garantida, do ponto de vista de nossa investigação racional. A liberdade constatada a partir da criação de um efeito no mundo sensível contrasta com a necessidade de explicaçáo das causas anteriores que conduziram à produção daquele efeito. 
Considerar, pois, nossos deveres geracionais implica compreender que os efeitos que produzimos não são todos pré-determinados. Essa compreensão e a sua recusa compóem um debate metafísico, no qual o termo contingência - quando a discussão trata da totalidade dos fenômenos - ou liberdade - geralmente quando lidamos mais especificamente com a ação humana - encontram seu significado em oposição à ideia de necessidade ou de causalidade. Esses termos sofrem variaçóes, dependendo dos autores ou de momentos filosóficos, mas usaremos os acima destacados por julgá-los suficientemente genéricos para permitir a compreensão do problema discutido. Se polarizamos os argumentos, concluiremos que ou há contingência dos efeitos, e as coisas e as pessoas possuem algum poder causal imanente; ou eles são pré-determinados, e a causa primeira de qualquer efeito é exterior e transcendente. No campo da ética, essa dualidade é muitas vezes dissolvida pela visão compatibilista, sobre o que trataremos adiante.

Nesse ponto, interessa notar que, assim como a questão da eternidade, o embate dialético entre necessidade e contingência foi abordado - dentro de redes conceituais diferentes, sem dúvida - ao longo de toda a história da filosofia. Porém, visto que buscamos problematizar filosoficamente a suposição da liberdade implícita na ideia de dever intergeracional, interessa-nos aqui mostrar a dúvida muito mais que as respostas. Assim, a fim de limitar a discussão, ela será tratada com base na obra de Kant (2001, p. B472-479).

O filósofo afirma que, segundo as leis da natureza, tudo o que acontece, isto é, que tem um início no tempo, pressupóe um estado anterior, a partir do qual o evento "[...] infalivelmente sucede segundo uma regra." (KANT, 2001, p. B472). Para que esse estado anterior tenha sido capaz de produzir um efeito, é necessário que ele também tenha tido um início no tempo, pois, caso ele sempre houvesse existido, o efeito que ele produziu também haveria existido sempre, já que não haveria mudança capaz de gerar um novo evento. Desse modo, não haveria sucessão alguma de acontecimentos, isto é, tudo o que é sempre teria sido. Investigando a origem do acontecimento pelo lado das causas - ou seja, realizando uma série ascendente de raciocínios -, a razão percebe que, se uma causa produziu um efeito, é porque ela também é efeito de uma causa anterior, e assim sucessivamente.

Se a relação entre causa e efeito ocorre segundo uma lei universal, sendo, portanto, necessária e não contingente - isto é, se, na natureza, uma causa específica só pode produzir um único efeito e não o efeito contrário -, deveremos considerar que, porque o homem nasce, isto é, tem um início no tempo, 
ele também estará sujeito a essas leis naturais. Assim, suas açóes, como tudo o que ocorre no mundo empírico, seriam resultado de uma causa precedente, a qual fez com que sua existência - e, logo, a ação realizada - se dessem de modo necessário. A essa causa precedente, como vimos, deve corresponder uma anterior - e isso ad infinitum. Isso significa que nenhuma ação poderia ser realizada diferentemente de como foi, já que toda a série de açôes ocorre segundo uma regra universal e não contingente.

$\mathrm{Na}$ seção analisada da Crítica da razão pura, Kant formula o motivo pelo qual as leis da causalidade natural poderiam contradizer a liberdade. Por um lado, como argumento racional de que essa causalidade acontece e que, então, tudo o que ocorre é pré-determinado, está o fato de que se considerássemos algo que não estivesse sujeito a essas leis e pudesse, pois, produzir espontaneamente um efeito, esse efeito não poderia tampouco possuir regra alguma, a fim de gerar um efeito posterior. Ou seja, ele não poderia funcionar como causa, para gerar um encadeamento de açôes (série), de modo que tudo seria produzido aleatoriamente, sem que houvesse leis naturais, porque, se um efeito se produz, sendo que poderia ser produzido seu contrário, ele não foi produzido por regra alguma e, igualmente àquilo que o produziu, não está sujeito a regras. Por outro lado, se a liberdade produzisse um efeito sempre segundo uma lei, "[...] não seria liberdade, seria tão-só natureza.” (KANT, 2001, p. B475).

Querendo encontrar um "repouso" na sua busca por uma "causa primeira”, a razão pensa uma causa incondicionada à qual chama liberdade. Isso, no entanto, seria apenas uma forma que ela encontra para não permanecer paralisada, diante do conflito consigo mesma, e permitir a ação do sujeito no mundo empírico. Sobre isso, afirma Kant:

Porém, nunca é lícito no mundo atribuir tal faculdade às substâncias, porque se assim fosse desapareceria em grande parte o encadeamento de fenômenos que se determinam necessariamente uns aos outros por leis universais, encadeamento a que se dá o nome de natureza, e, com ele, o caráter da verdade empírica, que distingue a experiência do sonho. Com efeito, a par dessa faculdade da liberdade, independente de leis, mal se pode pensar a natureza, porque as leis desta última seriam incessantemente alteradas pelas influências da primeira e o jogo de fenômenos, que, pela simples natureza deveria ser regular e uniforme, ficaria desse modo perturbado e desconexo. (KANT, 2001, p. B479).

Em resumo, a natureza se opóe à liberdade, e seríamos levados a pensar 
que apenas uma das duas existe. Segundo o próprio autor, é essa dificuldade de explicar os movimentos do mundo que haveria conduzido os filósofos antigos a admitirem um "primeiro motor".

Por outro lado, o argumento da razão que contraria essas afirmações seria o de que, quando consideramos a causalidade, pensamos obrigatoriamente em um estado que possa ter sido anterior ao efeito e que o produziu. Quando tentamos tudo explicar conforme o princípio da causalidade, no entanto, "[...] haverá sempre apenas um começo subalterno, nunca um primeiro começo, e não há, portanto integridade da série do lado das causas provenientes umas das outras." (KANT, 2001, p. B472-474). Se essa lei da natureza diz que nada pode acontecer sem uma "causa suficiente determinada a priori", a explicação determinista, ao não conseguir encontrar uma causa primeira, entraria em contradição consigo mesma. Por esse motivo, temos que admitir que possa haver uma espontaneidade absoluta, capaz de dar início a uma série de fenômenos que se desenvolvem de acordo com a lei da natureza. Essa seria uma liberdade transcendental, já que, para que seja, de fato, liberdade, não poderia estar sujeita às leis naturais.

Essa questão sobre a possibilidade ou não da liberdade coloca-se para a razão pura, a qual possui caráter especulativo e não pode, sozinha, orientar a ação humana, porque esse conflito de ideias, o qual possui argumentos lógicos que se refutam reciprocamente - o que, segundo Kant, as comprova - jamais pode ser inteiramente resolvido. Essa dialética, chamada de transcendental, encontra sua peculiaridade no fato de que a razão pura só pode descobrir as aparências dos juízos que empreende (KANT, 2001, p. B350-355). Para a ação, usamos a razão prática, que não precisa explicar a liberdade:

Também não é necessário encontrar resposta para a interrogação acerca do modo como será isto possível [uma causalidade incondicionada, que origina uma série de acontecimentos] [...], pelo que, temos de ater-nos simplesmente à experiência. [...]. Ficando assim provada, embora não compreendida em si mesma, a faculdade de começar espontaneamente uma série no tempo, é-nos lícito também no curso do mundo fazer começar, espontaneamente, séries diversas quanto à causalidade e conferir às substâncias dessas séries uma faculdade de agir pela liberdade. (KANT, 2001, p. B476 - 478).

Importa sublinhar, nesse último trecho, a distinção entre provar e compreender, a qual remete à distinção kantiana entre pensar e conhecer. Por meio 
de um esforço intelectual, a razão permite-nos provar tanto a possibilidade quanto a impossibilidade de nossa liberdade, diante da natureza. Em passagem posterior, Kant chega a afirmar que os dois tipos de causalidade - natural e por liberdade - não são opostas: "[...] ambas se verificam independentemente uma da outra e sem que uma à outra se perturbem.” (KANT, 2001, p. B585). O ponto a ser notado aqui é que não podemos fazer uso adequado dessas conclusóes, na prática, e nem no raciocínio prático, motivo pelo qual, para o agir, partimos sempre da experiência, que nos faz pressupor a liberdade.

Quando se busca agir segundo o dever, como implícito na ideia de que temos deveres em relação às geraçôes futuras, precisamos partir do entendimento de que os impactos que geramos sobre essas geraçôes, isto é, os efeitos que produzimos, são contingentes e não são apenas resultados diretos da ação das leis naturais. A produção desses impactos depende, por conseguinte, do uso da liberdade para definir tanto os objetivos das ações quanto os modos de proceder.

Cabe-nos, então, representar a liberdade, não porque queremos mostrar-nos como algo que não somos, ou seja, simular (BACON, 1952) nossa condiçâo livre, mas justamente porque não conhecemos a verdade sobre nossa própria condição e, portanto, nenhuma representação poderá ser dita falsa - por mais que continue a ser representação. Essa representação, nós a realizamos dia após dia, pois, mesmo que quiséssemos não escolher livremente, relegando nossa responsabilidade para algo exterior e/ou superior, simplesmente não saberíamos como agir e nem mesmo decidir sobre a ação ou a inércia. Assim, diante da incerteza, cabe a escolha, aparentemente livre, sobre se agiremos conforme ou contrariamente à ideia de liberdade. Essa é a condiçáo de cada um, e o modo como a entendemos pode determinar a condição de todos em conjunto.

\section{SOMOS RESPONSÁVEIS POR NOSSAS AÇÓES}

Qualquer teoria moral parte do reconhecimento de que algum grau de liberdade pode ser exercido na esfera metafísica, ética, social ou em todas elas. Isso não quer dizer que a teoria moral rejeitará por completo a causalidade. Como em Kant, é possível entender que causalidade e liberdade funcionam em âmbitos diferentes - fenômeno e noumeno, respectivamente - e que, pois, não há sobreposição de uma em relação à outra. Além disso, a ideia de determinaçáo náo implica forçosamente a necessidade de cada ato, contudo, pode se 
referir apenas à inexistência de possibilidades contingentes no resultado final. Como na ideia de destino, é possível pensar uma solução conciliadora, na qual o ponto final do conjunto das açóes esteja previamente definido, mas que se considera, ao mesmo tempo, que o percurso até este ponto - ou as açôes particulares - se encontra aberto a possibilidades diversas. Embora não possa ser totalmente desvencilhada do problema metafísico que apontamos, esse tipo de resposta ao problema, que tende para a chamada solução compatibilista, é frequente no campo da ética, já que não faz sentido buscar juízos sobre modos corretos de ação para sujeitos que não podem definir como agir.

A noção de responsabilidade, por consequência, pressupóe a de liberdade, mas esta última é insuficiente para dar significado completo à primeira. Isenta de conotação valorativa e em seu significado mais amplo possível, a liberdade pode ser entendida, a partir da definição de Hobbes, como "[...] a ausência de impedimentos externos, impedimentos que muitas vezes tiram parte do poder que cada um tem de fazer o que quer [...]" (HOBBES, 2003, I, XIV, p. 112). Ou seja, a liberdade é, grosso modo, o poder fazer, e portanto, nessa definição minimalista, significa a possibilidade do exercício absoluto das capacidades individuais. Não é por acaso que a liberdade se apresenta, no autor inglês, como elemento central a produzir um estado de natureza caótico, no qual nenhuma responsabilidade pode ser cobrada.

$\mathrm{O}$ dever exige liberdade, mas comporta, ao mesmo tempo, alguma restrição. Na medida em que essa restrição é apresentada ao indivíduo, a partir de um poder exterior, passamos ao campo da responsabilidade política ou jurídica. No entanto, essa limitação pode ter origem interior, na razão individual - ou naquilo que ela interioriza de razóes externas - e, nesse caso, lidamos com um dever e uma responsabilidade que chamamos moral. Trata-se de uma limitaçáo imposta à liberdade pelo próprio indivíduo, o qual possui a capacidade de utilizá-la.

O dever moral requer um critério em vista do qual ele possa ser julgado. Pelo menos até o fim da Idade Média, a ideia de bem, embebida de conotações metafísicas ou religiosas, foi considerada como critério absolutamente válido. Um ponto de inflexão, contudo, surgiu em um autor cujas obras não possuíam a pretensão imediata de elaborar uma teoria moral: Maquiavel. No pensador florentino, o dever ser ou o dever fazer estáo geralmente colocados em vista da manutenção ou expansão do poder do indivíduo ou da cidade. Daí a emblemática passagem em que o autor refuta a interpretação do frei Savonarola, segundo a qual o processo de "decadência italiana", que se verificou no fim do século XV, com a invasão francesa e as desordens internas, era resultan- 
te dos pecados. Em explícito tom polêmico, o autor afirma que aqueles que diziam que a situação da Itália eram os "nossos pecados" (peccati nostri) não haviam errado, mas não se tratava daqueles que pensavam ser, senão dos "pecados dos príncipes” (peccati di prinicipi). Assim, porque os deveres dos príncipes - na passagem, o de possuir um exército próprio - não foram observados, “[...] eles também sofreram as suas penas.” (MAQUIAVEL, 2007, XII, p.128-129). Maquiavel distingue, portanto, a transgressão do dever moral na perspectiva tradicional - isto é, o pecado - do não cumprimento do dever imposto pela política - daí os comentadores tratarem da autonomia da política, no autor.

Nessa perspectiva, o dever moral deixa de ser algo válido para todas as situações da ação humana, como nas ideias de bem e de justo, e passa a referir-se ao que é simplesmente correto, avaliado com padróes e objetivos estabelecidos por convenção, por interesse, ou mesmo arbitrariamente: "Um ato é correto ou incorreto (rectum aut minus rectum) em geral na medida em que se conforma ao dever ou é contrário a este (factum licitum aut illicitum); o dever ele mesmo, em termos de seu conteúdo ou origem, pode ser de qualquer tipo." (KANT, 2003, p. 66-67, grifo nosso). Mesmo nesse dever desprovido de conteúdo universalmente válido, contudo, percebe-se liberdade e limitaçâo nas noçóes de transgressão e conformidade, pois o agir corretamente implica orientar as açôes com vistas a um fim.

Sob certo aspecto, então, ao formularmos nosso dever, afirmamos a liberdade para poder limitá-la, e pensar como a liberdade limitada pode ser considerada livre desafia as teorias morais. A resposta está em uma limitação autoimposta, ideia que abandona a concepção minimalista acima mencionada e redefine o termo liberdade com base em um significado moral.

Em sentido moral, deveremos considerar que a ação será livre, se a limitação a ela tiver origem no próprio sujeito da liberdade. Se o movimento for determinado por algo exterior, não há liberdade, porque a motivação não pertence à sua individualidade. No caso mais simples e direto, temos o exemplo do movimento animal por instinto, causado por impulsos pré-determinados pela natureza. Entende-se que, mesmo sem ter seu movimento limitado por nenhum obstáculo físico, ele jamais poderá ser considerado livre, porque é incapaz de escolher agir contrariamente aos impulsos que recebe do exterior.

Os impulsos naturais agem também sobre o ser humano, devido à sua condição biológica. Há, contudo, para os indivíduos, impulsos que podemos genericamente chamar de psicológicos, pois são produzidos pelas paixóes. Não 
raro, essas paixóes foram concebidas como componentes negativos do ser humano - daí derivarmos também do étimo da palavra o patológico - por se entender que eram contrárias à liberdade. Segundo essas concepçóes filosóficas, o que evita a submissão total do indivíduo aos impulsos naturais ou psicológicos é o uso da razão. Platão expóe esse entendimento na sua teoria da alma, na qual a ação justa do ser humano é aquela na qual o "elemento racional" comanda as partes apetitiva e irascível (PLATÃO, República, IV, 439c-d).

Em Aristóteles, vemos as paixões humanas serem subordinadas a um elemento imprescindível à ação virtuosa: o autodomínio (ekrateia). Todo o livro VII da Ética a Nicômaco aborda o tema, relacionando-o com outras "disposições louváveis", como a perseverança, a sensatez (fronesis) e a temperança, opondo-o às paixôes, aos prazeres e aos elementos que levam o sujeito à falta de domínio de si (akrasia). O autodomínio permite que a determinação interna - isto é, que o indivíduo definiu para si, ao aplicar as regras gerais ao caso concreto - se torne a ação diante das situaçôes específicas: "[...] quem se domina permanece fiel às determinações do seu cálculo, enquanto quem não se domina está inclinado a traí-lo." (ARISTÓTELES, Ética a Nicômaco, VII, 1, 2009, p. 1145b1). Visto que a prudência ou a sensatez dependem necessariamente desse cálculo, nenhuma ação prudente é possível, por consequência, sem autodomínio.

A não submissão do indivíduo aos impulsos constitui também tema da ética kantiana. No autor, o agir deve mostrar-se livre tanto dos impulsos relativos às coisas quanto do constrangimento derivado de outras pessoas. $\mathrm{O}$ conceito de autonomia, que fundamenta a noção de liberdade moral em Kant, consiste nessa capacidade do indivíduo de dar-se uma orientação exclusivamente a partir do interior ou de fazer com que a razão pura possa representar um fim como algo objetivo. A ética, portanto, "[...] produz uma matéria (um objeto da livre escolha), uma finalidade da razáo pura que ela representa como uma finalidade que é também objetivamente necessária, isto é, uma finalidade que, no que concerne aos seres humanos, é um dever possuir [...]" (KANT, 2003, II, p. 225).

Por meio da noçáo de autonomia, o autor conduz a liberdade humana ao extremo - e ao excesso, diriam alguns. A partir dela, a ética kantiana elabora, por um lado, a ideia de dignidade humana, na qual cada indivíduo deve ser considerado como "fim em si mesmo". Por outro, porém, ela distancia o ser humano de suas relaçóes reais, aproximando-o do sagrado e tornando o indivíduo, ou a noção geral de humanidade, superior à ordem natural e política:

Tudo o que existe na criação e sobre a parte que se tenha suficiente poder, poderemos empregar como simples meio; unicamente o homem, e com ele 
toda a criatura racional, é fim em si mesmo. É ele, efetivamente, o sujeito da lei moral, que resulta santa graças à autonomia da sua liberdade. (KANT, 2004, I, 3, p. 176).

Autores posteriores apontarão os descaminhos da ética kantiana, argumentando que o conceito de liberdade como autonomia é excessivo e abre espaço para que a ética volte a ser pensada em termos metafísicos. Essas críticas se referem também à impossibilidade de uma liberdade absoluta do sujeito em definir suas próprias açóes e seus próprios fins a priori e sem a interferência de fatores empíricos - representados pela razão. A condição biológica, psicológica e social do ser humano leva-o a sofrer interferências do meio e de suas experiências, o que influencia cada ação em particular e a própria escolha do fim. Argumenta-se, por fim, que a liberdade relativamente ao meio natural e social não apenas leva em conta esses fatores, mas que deve mesmo levá-los em consideração, e não excluí-los, para a formulação do dever.

De fato, a noção de responsabilidade chega-nos a partir do entendimento de que não somos simples coisas submetidas às leis naturais, de que nossa ação náo é determinada pela atração ou repulsão que os objetos provocam nos sentidos, e de que náo somos apenas o resultado de um meio social inflexível sobre a personalidade dos indivíduos. Uma ética fundamentada nas ideias de autonomia e dignidade humana pode até ser suficiente para alinhar cada um à sua própria consciência. Mais ainda, há possibilidades caso aceitemos a capacidade da razão prática em equilibrar adequadamente a liberdade do conceito de autonomia, por um lado, com as restriçóes derivadas do imperativo categórico, por outro - de que uma ética assim formulada permita uma boa convivência entre o sujeito e os indivíduos que se encontram ao redor. Não obstante, a partir das discussões filosóficas, mas também da experiência - que tem nos tornado conscientes de que geramos cada vez mais degradação futura, em termos ambientais e sociais -, percebemos que a responsabilidade do indivíduo deve considerar as relações dos seres humanos com outras formas de vida e com aquilo que é apenas provável - a existência das geraçóes futuras e o futuro da vida como um todo.

Essa é uma nova exigência ética frente ao poder que a tecnologia nos conferiu, o qual faculta não apenas alterar a natureza, mas destruí-la. Em termos de espécie, esse novo poder implica mais liberdade, e esta, se não deve ser destrutiva, e ao mesmo tempo, se não pode ser controlada desde o exterior, 
precisa encontrar novos limites internos.

\section{O PODER TECNOLÓGICO E A NOVA ÉTICA}

A responsabilidade do indivíduo reflete a construção de sua personalidade, já que é pelo fim que ele coloca a si mesmo e pelo dever daí resultante que as individualidades se manifestam. No contexto do novo poder da humanidade, a responsabilidade vai além disso e diz respeito à participação de cada um nesse ambiente, cujo futuro a própria humanidade pode determinar. Assim, um pensamento ético que sirva para nos orientar em relação às geraçóes futuras deve entender que somos responsáveis em conjunto por efeitos que geramos separadamente. Para que isso seja possível, em um mundo de pluralismo ético e riscos tecnológicos, a liberdade é nossa condição. Apenas a partir dela seremos capazes de pensar o dever de todos, e orientar nossas ações em um contexto no qual, justamente porque tudo está incluído, não há heteronomia possível.

Visando a analisar a ameaça das tecnologias para a permanência da vida na Terra e a consequente exigência de uma nova ética capaz para enfrentar esse desafio, Hans Jonas escreveu $O$ principio responsabilidade, ensaio de uma ética para a civilizaçâo tecnológica. Para o autor, mesmo que o homem nunca tenha estado desprovido de técnica, a enorme capacidade para afetar as condiçóes de vida da técnica moderna gera um novo desafio ético. De fato, até recentemente, tudo o que o homem criou pouco ou nada afetara a Natureza.

Sua vida desenvolveu-se entre o que permanecia e o que mudava: o que permanecia era a Natureza, o que mudava eram suas próprias obras. A maior dessas obras era a cidade, à qual ele podia emprestar um certo grau de permanência por meios que inventava e aos quais se dispunha a obedecer. (JONAS, 2006, p. 33).

Mas, mesmo essa obra humana, a polis, podia ser destruída pelo acaso, pelo destino, ou pela estupidez humana, como retrata a tragédia grega clássica. Diante da Natureza, toda poderosa, apenas a astúcia e a criatividade auxiliavam o homem. A ética tradicional, portanto, estava circunscrita àquele espaço intra-humano, a comunidade política, na qual o indivíduo poderia interferir significativamente. Por isso, segundo Jonas, toda a ética tradicional 
é antropocêntrica, tendo em vista apenas o relacionamento do homem com o homem, incluindo o relacionamento de cada homem consigo mesmo (JONAS, 2006, p. 35). Correspondiam à modéstia das tecnologias disponíveis os impactos igualmente modestos do seu emprego sobre a Natureza, que podiam ser avaliados no âmbito do aqui e agora. Entretanto, as tecnologias modernas, que alteram profundamente o clima, a sobrevivência das espécies animais, que esgotam recursos e que pretendem alterar a própria natureza do homem, necessitam ser avaliadas de outra forma. É preciso considerar suas consequências a longo prazo para as futuras geraçôes, bem como para todo o planeta.

As recentes tecnologias conferem novas dimensóes à responsabilidade. Em primeiro lugar, descobrimos que a Natureza se tornou vulnerável a nossa ação, o que é sem precedentes na história humana. Essa percepção conduz ao surgimento da Ecologia. Reconhecemos também que é difícil estimar o impacto de nossas açóes no tempo e no espaço, e que ele é, muitas vezes, irreversível. E justamente porque agora temos o poder de afetar a Natureza, de forma definitiva, diz Jonas, tornamo-nos responsáveis por ela.

As circunstâncias criadas pela era tecnológica estabelecem também uma relação especial entre ciência e moral. Distinguir o bem do mal agora requer um saber suficientemente sólido para orientar a nossa ação. Faz parte de tal saber, contudo, reconhecer que não podemos antever com exatidáo a consequência final de muitas das nossas açóes.

Reconhecer a ignorância torna-se, então, o outro lado da obrigação de saber, e com isso torna-se uma parte ética que deve instruir o autocontrole, cada vez mais necessário, sobre nosso excessivo poder. Nenhuma ética anterior vira-se obrigada a considerar a condiçáo global da vida humana e o futuro distante, inclusive da espécie. $\mathrm{O}$ fato de que hoje eles estejam em jogo exige, numa palavra, uma nova concepçáo de direitos e deveres, para a qual nenhuma ética e metafísica antiga pode sequer oferecer os princípios, quanto mais uma doutrina acabada. (JONAS, 2006. p. 41).

De fato, até a modernidade, a ética lidava com o presente. A ética religiosa, por exemplo, que se propunha sacrificar o presente com vistas à vida eterna, recomendava a vida ascética, porque essa era a verdadeira e santa maneira de se viver a vida terrena (JONAS, 2006, p. 52). O mesmo pode ser dito das exigências de responsabilidade do homem público e daquelas feitas aos pais perante os filhos. Embora mirem o futuro, são éticas do imediato. Buscam reproduzir, no futuro, aquilo que hoje consideram como sendo o Bem 
(JONAS, 2006, p.54).

Assim, somente com a noção de progresso é que surge a ideia de que o presente possa ser apenas a condição para o futuro, e de que esse futuro deva orientar a política do presente. Um futuro desconhecido, mas certamente melhor, fundado em uma natureza dominada para melhor nos servir, e mesmo um homem novo, sem as insuficiências físicas, psíquicas e intelectuais. Mas, segundo Jonas, os projetos do prolongamento da vida rumo à imortalidade, o controle dos comportamentos antissociais e a manipulação genética visando ao homem perfeito escondem grandes desafios éticos. Como garantir a imortalidade, na Terra, para os atuais viventes sem proibir os nascimentos? Quais características humanas deveriam ser eliminadas? Quem decide a respeito? Todas essas questóes, altamente complicadas de um ponto de vista ético e político, deveriam ser resolvidas antes que a tecnologia começasse a buscar e a produzir tais resultados. $\mathrm{O}$ mesmo cuidado caberia no caso de tecnologias que possam alterar a Natureza, de forma irreversível e imprevisível, ou que possam produzir acidentes de grande envergadura.

Quando, pois, a natureza nova do nosso agir exige uma nova ética da responsabilidade de longo alcance, proporcional à amplitude do nosso poder, ela também exige, em nome da responsabilidade, uma nova espécie de humildade [...]. Em vista do potencial quase escatológico dos nossos processos técnicos, o próprio desconhecimento das consequências últimas é motivo para uma contenção responsável - a melhor alternativa, à falta da própria sabedoria. (JONAS, 2006, p. 63).

A crítica aos impactos da técnica sobre a vida social não foi objeto apenas da reflexão de filósofos como Marcuse, Habermas ou Castoriadis, mas também de cientistas sociais, como Edgar Morin e Ulrich Beck. Este último criou o termo sociedade de risco para designar uma época da nossa história na qual a produçáo social de riqueza é sistematicamente acompanhada pela produção social de riscos, ainda que esses sejam bastante diferentes daqueles riscos que conhecemos no passado. Esses explicavam-se pela ausência de ciência e tecnologias desenvolvidas capazes de nos garantir alimentação, saúde e abrigo adequados, enquanto aqueles decorrem dos próprios avanços tecnológicos (BECK, 2010). A tecnociência, que posiciona a ciência a serviço da técnica e inverte a relação entre epistéme e téchne, mostra-se ambivalente, pois ela melhora nossas condiçôes de vida, ao mesmo tempo em que gera novos riscos. Com ela, a humanidade se salva das necessidades impostas pela natureza, en- 
quanto se condena pelos efeitos de sua própria liberdade.

Os novos riscos assumem caráter global e são pouco evidentes, antes que se concretizem em danos, pois sua avaliação prévia exige conhecimentos especializados. No entanto, à medida que ocorrem acidentes, instaura-se a desconfiança em relação às novas tecnologias. Remédios retirados de circulação, acidentes nucleares, doenças desconhecidas resultantes de novas práticas agropecuárias, enfermidades resultantes da ingestão contínua de agrotóxicos ou da poluição do ar.

O significado de risco relaciona-se, portanto, a danos que ainda não ocorreram e precisariam ser evitados. Ou seja, baseia-se numa certa antecipação e numa perda de confiabilidade geral, que, por sua vez, conduz as autoridades públicas à adoção de medidas preventivas, quase sempre insuficientes, para evitar novas ocorrências de danos (BECK, 2010, p. 39).

Tais riscos são difíceis de evitar, por estarem associados a causas sistêmicas do modo de vida moderno. Isso se revela na dificuldade de apuração das responsabilidades jurídicas, políticas ou individuais, quando ocorrem grandes acidentes. Tecnologias complexas, de grande porte, que requerem o funcionamento exemplar de uma série de sistemas interligados potencializam as probabilidades de falhas mecânicas ou humanas, em qualquer momento do seu uso. Percebe-se aí que o que está em jogo é o próprio modelo de produção adotado, assim como as noçóes de "progresso", "crescimento econômico" e "racionalidade científica", a ele associadas.

Beck acredita que, embora os críticos da sociedade de risco sejam sistematicamente desqualificados como alarmistas ou céticos, a sua realidade acaba por se impor, pelos acidentes, pela contaminaçáo crônica, pelo medo de novos acidentes e impactos. Evidencia-se, desse modo, a modernidade reflexiva, noção que designa que os efeitos indesejados dessa sociedade se refletem sobre ela e que, por isso mesmo, ela se vê obrigada a refletir acerca das técnicas e tecnologia a serem empregadas.

Diante dessa realidade, emerge uma comunidade objetiva de caráter global, pois os riscos não se detêm nas fronteiras nacionais. Isso não significa obrigatoriamente que uma crescente solidariedade se constitua, no planeta. Ao contrário, novos conflitos surgem, além daqueles já conhecidos, como o da luta de classes. A luta entre os atingidos pelos riscos e seus perpetradores cresce, e aumenta também o poder da ciência e o da mídia, que organiza e dissemina o conhecimento sobre as avaliaçóes de risco divergentes em relação 
às tecnologias: "A sociedade de risco é, nesse sentido, também a sociedade da ciência, da mídia e da informação. Nela, escancaram-se assim novas oposiçóes entre aqueles que produzem definiçóes de risco e aqueles que as consomem." (BECK, 2010, p. 56).

O desenvolvimento científico-tecnológico torna-se, portanto, contraditório, já que causa os problemas que enfrentamos, ao mesmo tempo em que se constitui no instrumento para compreendê-los e na fonte de soluçôes para os mesmos. De acordo com Beck, por enfrentar as consequências indesejadas do seu sucesso, a ciência experimentaria hoje uma segunda criação, na qual ela se volta contra si mesma, criticando seus próprios métodos e resultados. Nesse quadro, quanto maior a crítica aos seus resultados negativos, mais se intensifica o debate interno e externo à comunidade científica, e mais forte é a tendência dessa comunidade a erigir barreiras e regras de autocensura. Assim, de rompedora de dogmas, a ciência ameaça se tornar uma construtora de tabus, pois, embora reconheça a importância da crítica como procedimento fundamental à sua práxis interna, suas correntes hegemônicas buscam impor às sociedades, de forma autoritária, o que acreditam ser a sua verdade, esforçando-se por esconder do público as divergências internas, ou tratando de desqualificar seus opositores. A exposição pública das divergências, contudo, aumenta a desconfiança das sociedades em relação à comunidade científica e conduz à desmistificação da ciência e, ao mesmo tempo, a uma desmonopolização do conhecimento cientifico (BECK, 2006, p. 236).

Nesse contexto de crítica da ciência, impóe-se o surgimento de uma outra ciência, capaz de autolimitar-se e se autocontrolar, que busque medir os efeitos colaterais, combater a superespecialização e abandonar a imputação de infalibilidade, investigando metodicamente os riscos e perigos, de maneira a nos fornecer um quadro do que está em jogo. Isso implicaria que a técnica abandonasse a economia e a eficiência como suas inspiradoras primeiras, e se abrisse à incerteza construída, para a ambivalência, a contextualidade social e a dúvida fundamental (BECK, 2010, p. 156).

Tal política tecnológica contraria, entretanto, o que tem sido a tônica dos Estados, os quais buscam estreitar os vínculos entre economia e desenvolvimento tecnológico, resultando em um aceleramento do ritmo das inovaçóes. Como a motivação para técnica, na modernidade industrial, é dada pela bus- 
ca do lucro, Beck dirá que a inovação técnica é dominada pela oferta e não pela demanda, eludindo, portanto, o debate democrático sobre os seus rumos. Tecnologias avançadas, como as de geração de energia nuclear ou de plantas transgênicas, contaram e contam com o apoio e financiamento públicos, e os bilhões aí empatados explicam os poucos recursos destinados à avaliação de seus riscos e consequências de longo prazo (BECK, 2010, p. 159).

Seria necessário, portanto, liberar a técnica desse cartel de interesses, dessa "feudalização econômica e política", pois só assim seria possível uma técnica precautória, que colocasse a proteçâo da humanidade e do meio ambiente acima de interesses econômicos e políticos. Semelhantemente à "heurística do medo" de Hans Jonas, em que o medo de prováveis efeitos negativos das nossas açôes nos ensinaria como agir, conduzindo-nos à prudência, Beck também propôe uma técnica que priorize a precaução, eliminando ramos industriais causadores potenciais de altos riscos e buscando identificar os possíveis riscos de novas tecnologias, antes de introduzi-las no "laboratório do mundo".

\section{CONSIDERAÇÓES FinaIS: nOVOS EQUILÍbRIOS}

A partir do que discutimos acima, parece-nos que o nosso dever fundamental - isto é, aquele sem o qual outros não podem ser formulados -, frente às geraçóes futuras, é o de aprendermos a lidar com a incerteza. $\mathrm{Na}$ história do pensamento ocidental, o processo pelo qual a certeza vem perdendo seu posto de guia da humanidade remonta ao alvorecer da ciência moderna e ao questionamento dos dogmas e das autoridades, porém, encontra expressão mais radical no século XX, com o desenvolvimento da física quântica e a crítica ao positivismo. A julgar pelas tendências atuais, se náo pudermos pensar em deveres, em um cenário de incerteza - sobre o futuro, sobre a liberdade, sobre o próprio conhecimento -, estaremos fadados à inércia de um consentimento acrítico àquilo que virá. Nesse caso, responderemos às nossas dúvidas insolúveis sobre o futuro e a liberdade, gerando um resultado que prova - náo racionalmente, mas empiricamente - a verdade da resposta negativa à questáo da continuidade do mundo e da existência da liberdade. Concluiremos, assim, uma profecia autorrealizável.

Ao contrário, se pudermos aceitar que a dignidade humana não está em saber e poder fazer tudo, na natureza, é possível que, mesmo sem compreender o papel do indivíduo no todo, sejamos capazes de agir como seres responsáveis. Dessa forma, aceitando a ignorância, por um lado, e ousando avaliar o que será 
melhor, por outro. Poderemos enfim utilizar da liberdade que acreditamos ter para desenvolver um senso de responsabilidade, geral o suficiente para proteger o planeta, e específica o suficiente para orientar a ação moral de cada um.

Partir da incerteza filosófica não nos impede de afirmar a certeza de outro fundamento para a definição dos deveres: a continuidade da vida depende da salvaguarda de suas condiçóes. Enquanto indivíduos e enquanto espécie, podemos errar e gerar o prejudicial, quando pretendíamos produzir o benéfico. No entanto, novas açóes não podem surgir sem que consideremos, em cada uma das decisões tomadas, se as escolhas feitas impossibilitam a manutenção contínua e indefinida da existência da vida. É, antes de tudo, a partir dessas avaliaçóes que devemos julgar nossas açôes. Esses são nossos deveres fundamentais: a incerteza sobre o conhecimento e a certeza de nossa condição. E convém reconhecer que, como no fundamento de uma edificação, é aqui que está o trabalho mais dispendioso.

No campo ambiental, esforços nesse sentido têm surtido efeito, ao se avaliar decisóes que podem ter grande impacto no futuro. A percepção de que novas tecnologias foram introduzidas no planeta, em um ritmo muito mais acelerado do que aquele que as próprias ciências tiveram para avaliar seus impactos, ou seja, a descoberta a posteriori dos riscos, motivou o surgimento do princípio da precaução, na legislação ambiental, como norma para avaliar a introdução de novas tecnologias no meio ambiente. Tal legislação surge concomitantemente, nos anos 70, na República Federal Alemã, sob o nome de Vorsogeprinzip, (LISBOA, 2009, p.118) e, na Suécia, com a legislaçáo que tratava de produtos tóxicos, o Act on products hazardous to man or to the environment. Ambas as legislaçóes exibem o princípio definidor da precaução, que é prevenir, mesmo que não haja certeza absoluta dos riscos inerentes a determinada tecnologia. A ideia de que é imperativo adotar decisões para evitar danos graves no futuro, na medida em que haja probabilidade de que eles ocorram, é, aliás, comum às diferentes definições do princípio da precaução presentes nos vários tratados ambientais internacionais em que ele foi reconhecido, desde então. O princípio da precaução difere do princípio da prevençâo, porque se refere às situaçóes nas quais não se pode ter certeza da possibilidade e da probabilidade de danos sérios resultantes de novas tecnologias (RAFFENSBERGER; TICKNER, 1999, p. 1).

As razóes dessa incerteza advêm justamente dos maiores poderes dessas tecnologias e das dificuldades em controlar todas as variáveis a elas relacionadas. Foram essas dificuldades que conduziram à busca de um novo paradigma, 
o paradigma da complexidade, e à aceitação de que a incerteza é um elemento constitutivo das interaçóes humanas com o mundo. Para investigar os possíveis impactos diretos, indiretos e cumulativos de uma nova tecnologia, por exemplo, é preciso reconhecer a existência não só de relações causais simples, mas de conexôes sistêmicas, efeitos sinergéticos, reaçôes retardadas, padróes indiretos de causação e processos caóticos de mudança.

Às insuficiências das avaliaçóes de risco que não se baseiam em um paradigma de complexidade devemos somar a assimetria social nas condiçóes de produçáo do conhecimento, que faz com que os proponentes de atividades potencialmente prejudiciais ao meio ambiente e à sociedade disponham de mais recursos técnicos para defendê-las, do que a sociedade leiga tem para investigá-las. Por isso, a inversão do ônus da prova é parte do princípio da precauçâo. Cabe ao proponente da tecnologia a obrigação de provar a sua segurança, ao invés de exigir que suas vítimas potenciais justifiquem seus temores.

Está implícita, portanto, no princípio da precaução, uma escolha ética: na dúvida, o legislador deve optar pelo meio ambiente, pela saúde pública, pelas partes mais fracas, em detrimento do interesse particular dos patrocinadores de tecnologias e seus beneficiados. Obviamente, contudo, devido às disputas políticas em torno dessas questôes éticas, a implementação desse princípio tem se mostrado difícil.

Diante da incerteza acerca das decisóes que terão impacto sobre todos e irão perdurar no tempo, cabe discutir quem tem legitimidade para tomar tais decisôes e segundo que valores e princípios. Desde o início da Idade Moderna, confiamos esse poder ao Estado, entendendo-o como único capaz de formular regras e finalidades públicas. Confiamos na capacidade de decisão de um indivíduo pretensamente mais esclarecido, ou na tecnicidade da administração burocrática supostamente desprovida de interesses. Relegamos os cidadãos ao âmbito privado, deixando-os sem poder, mas, não raro, sem motivação para participar das decisóes públicas.

Cabe-nos agora criar instâncias nas quais as ambivalências das nossas escolhas possam ser discutidas e, de preferência, consensualizadas. Além de conselhos, nos quais a sociedade civil detém parte dos assentos, há hoje no mundo várias experiências para incluir setores mais amplos das sociedades nos processos decisórios, como "painéis de cidadãos", comissóes de investigação, além das já tradicionais consultas públicas, como referendos e plebiscitos. No campo ambiental, todas as legislaçóes atuais possuem processos de avaliação 
de impactos e de riscos. Temos, então, experiências que precisam ser ampliadas para garantir a participação popular.

O simples conhecimento dessas experiências pode inspirar novas formas de tomada de decisóes, nos diversos campos sociais. Nesse sentido, a circulação da informação é essencial. Assim, é preciso garantir a informação ampla e irrestrita, para que a falta de conhecimento não determine o resultado dos debates públicos. Todavia, além disso, a informação é necessária, para que a participação ampla não resulte em algo semelhante àquilo que Tocqueville chamou de tirania da maioria, para que se possa tomar decisóes informadas a propósito dos objetos de discussão.

Abertura dos processos decisórios e informação são condiçôes, mas não garantia de participação individual e popular nos rumos da sociedade e do planeta. Sem a igualdade que permite usar essas informaçóes, a participaçáo não passaria de uma farsa. Por conseguinte, para que haja liberdade política, precisamos redistribuir os recursos da produção social, uma percepção que não é nova, mas que não se efetiva devido à força que mantém um status quo em benefício de alguns. Esse esforço, contudo, deve ser concomitante àquele que visa a incluir os indivíduos nos processos decisórios, a fim de que nenhum dos dois se torne apenas promessa.

De fato, liberdade e igualdade de acesso aos recursos materiais sustentam-se mutuamente, e não se encontram em lados opostos da balança, como muitas vezes se argumentou. Na construção de uma sociedade justa, liberdade e igualdade estão do mesmo lado, e desordens e riscos, do outro. Certamente, essa balança jamais ficará estanque, uma vez que os absolutos - a liberdade, a igualdade, a segurança e a ordem absolutas - não pertencem à esfera humana. Mesmo assim, o comprometimento com a busca incessante desse equilíbrio é o caminho que permitirá às geraçóes futuras modificar a sociedade e buscar a possibilidade náo apenas de uma vida, mas de uma boa vida. Só assim estaremos certos de que as decisóes que tomamos, na incerteza, poderâo ser rejeitadas, caso se verifiquem nefastas.

A revisão das decisôes necessita ainda de mais uma garantia, pelo que retomamos o início da presente reflexão: a de que haverá futuro. Portanto, nossas decisóes não devem impossibilitar novas escolhas. Apesar de todas as divergências, devemos ser capazes de chegar a um acordo mínimo que garanta que os resultados dos debates públicos apenas serão legitimados, quando não representarem ameaças à própria existência do futuro ambiental e humano. $\mathrm{O}$ 
fundamento ético das políticas tecnológicas deveria ter como norte, seguindo a proposta de Hans Jonas, mas também da grande maioria dos movimentos ambientalistas, a preservação da vida em geral e, em particular, a vida da humanidade, assim como ela chegou até nós: "Aja de tal forma, a que os efeitos da tua ação sejam compatíveis com a permanência de uma autêntica vida humana sobre a Terra." (JONAS, 2006, p.47).

É tarefa da filosofia contemporânea, pois, conduzir esse debate, de cujos resultados dependerá o curso mais temerário ou mais prudente das geraçôes atuais em relação às futuras. Para isso, convém sermos menos pretensiosos e pensar a liberdade e a responsabilidade, conceitos aparentemente atemporais, dentro das exigências do momento histórico. Essa tarefa não é de menor importância do que a elaboração de conceitos universais, entretanto, ela parte de outra perspectiva, a de que buscar a ação correta significa tomar consciência do impacto temporal das nossas açóes.

Devemos, por fim, aprender a usar liberdade do ser humano, estimulando-o a encontrar soluçóes para as nossas dificuldades, diante da natureza e do convívio social, mas a limitando, para que náo exceda a capacidade do planeta. A liberdade absoluta nos faz indiferentes ao tempo e espaço e, desse modo, superiores à natureza. A autolimitação de nossa liberdade deve ensinar-nos que, em muitos casos, devemos ceder a esse universo, ao invés de buscar dominá-lo sempre.

Ao fim, isso culmina na percepção de que apenas nos redimensionando poderemos encontrar nosso verdadeiro espaço de vida. Em vista disso, nosso dever é encontrar, na nossa dignidade, a grandeza que nos torna únicos em nosso ser, em nossas açóes e em nossas construçóes; e, na nossa humildade, a pequenez que nos faz ser parte, e ter participação, mas não controle, naquilo que nos é maior. Em síntese, devemos equilibrar esses extremos de dignidade e humildade do ser humano, os quais se manifestam em cada um de nós com respeito à sociedade e, na humanidade, em relação ao planeta.

TEIXEIRA JÚNIOR, G. A.; LISBOA, M. V. Intergenerational duties: how can we define them from the standpoint of philosophy. Trans/form/ação, Marília, v. 41, n. 1, p. 31-60, Jan./Mar., 2018. 
ABSTRACT: Debates on our duties to future generations are increasingly urgent if we consider the individual, social, and human degradation of the present day. This article points out the philosophical complexity that underlies these debates, first indicating that the following assumptions are present in every statement concerning our duties to future generations: 1) there will be future generations; 2) our actions are contingent; 3 ) we are responsible for the way our actions impact future generations. The first three sections discuss each of these assumptions by presenting the debates over the eternity of the world, the existence of freedom, and the idea of duty. In the following sections we present the convergent ideas of Hans Jonas and Ulrich Beck, so as to argue that as technology has given humankind an unprecedented power over the world, a new kind of ethical thought is required. Finally, taking into account the idea of incertitude that arises both from the philosophical issues discussed and from our current techno-scientific context, we conclude by arguing that we should formulate our duties regarding future generations and specify those that are our main obligations.

KeYwORDs: Future, Uncertainty, Technology, Intergenerational ethics, Intergenerational duty.

\section{REFERÊNCIAS}

ABBAGNANO, N. Dicionário de filosofia. Tradução de Alfredo Bosi. São Paulo, Martins Fontes, 2007.

AGOSTINHO. Confissóes; De magistro. Tradução de J. Oliveira Santos e A. Ambrosio de Pina. Sáo Paulo: Abril Cultural, 1980.

ARISTÓTELES. Ética a Nicômaco. Tradução de António de Castro Caeiro. São Paulo: Atlas, 2009.

BACON, F. Ensaios. Lisboa: Guimarães \& Cia., 1952.

BECK, U. La Invención de lo politico: por una teoria de la modernización. S.L.: Fondo de Cultura Economica de España, 2001.

. Sociedade de risco: rumo a uma outra modernidade. Tradução de Sebastião Nascimento. São Paulo: Editora 34, 2010.

BREDEKAMP, H. Stratégies visuelles de Thomas Hobbes: Le Léviathan, archétype de l'état moderne. Traduçấo de Denise Modigliani. França: Editions MSH, 2003.

HOBBES, T. Leviatã ou matéria, forma e poder de uma república eclesiástica e civil. Tradução de João Paulo Monteiro e Maria Beatriz Nizza da Silva. São Paulo: Martins Fontes, 2003.

HUME, D. Investigação acerca do entendimento humano. Tradução de Anoar Aiex. São Paulo: Nova Cultural, 1996.

JONAS, H. O princípio responsabilidade: ensaio de uma ética para a civilização tecnológica. Tradução de Marijane Lisboa e Luiz Barros Montez. Rio de Janeiro: Contraponto; Editora PUC-Rio, 2006.

KANT, I. Crítica da razão pura. Traduçáo de Manuela Pinto dos Santos. Lisboa: 
Fundação Calouste Gulbenkian, 2001.

. A metafísica dos costumes. Tradução de Edson Bini. Bauru: Edipro, 2003.

- Crítica da razão prática. Tradução de Afonso Bertagnoli. (Digitalização da edição em papel da Ediçóes e Publicaçóes Brasil Editora S.A. São Paulo, 1959). São Paulo: EBooks Brasil, 2004.

KANTOROWICZ, E. The king's two bodies: a study in medieval political theology.

Princeton: Princeton University Press, 1997.

LAO-TSÉ. Tao te King. Blumenau: Eko, 2007.

LISBOA, M. O fundamento ético do princípio da precaução. Margem, Faculdade de Ciências Sociais, PUC-SP, São Paulo, n. 21, p. 77-91, jun. 2005.

- Ética e cidadania planetária na era tecnológica: o caso da convenção da Basileia.

Rio de Janeiro: Civilização Brasileira, 2009.

MAQUIAVEL, N. O príncipe. Tradução de José Antônio Martins. São Paulo: Hedra, 2007.

MEYER, L. Intergenerational justice. In: ZALTA, E. N. (Ed.). The Stanford Encyclopedia of Philosophy .2010. Disponível em: <http://plato.stanford.edu/archives/spr2010/entries/ justice-intergenerational/>. Acesso em: 05 out. 2014.

PLATÃO. A república. Tradução e organização de J. Guinsburg. São Paulo: Perspectiva, 2006.

. Timeu-Critias. Tradução de Rodolfo Lopes. Coimbra: Centro de Estudos

Clássicos e Humanísticos da Universidade de Coimbra, 2011.

RAFFENSPERGER, C.; TICKNER, J. Protecting public health \& the environment: implementing the precautinary principle. Washington D.C.; Covelo, California: Island Press, 1999.

SENELLART, M. As artes de governar. Tradução de Paulo Neves. São Paulo: Editora 34, 2006.

SHAKESPEARE, W. Hamlet, príncipe da Dinamarca. Tradução de F. Carlos Ameirda Cunha Medeiros e Oscar Mendes. São Paulo: Abril Cultural, 1978.

SKINNER, Q. As fundaçóes do pensamento político moderno. Tradução de Renato Janine Ribeiro e Laura Teixeira Motta. São Paulo: Companhia das Letras, 1999.

SPITZ, J-F. Humanisme civique. In: RAYNAUD, P.; RIALS, S. (Dir.). Dictionnaire de philosophie politique. Paris: PUF, 1996.

WIENER, N. Cibernética e sociedade: o uso humano de seres humanos. Tradução de José 
TEIXEIRA JÚNIOR, G. A.; LISBOA, M. V.

Paulo Paes. São Paulo: Cultrix, 1968.

Recebido: 03/09/2015

Aceito: 24/08/2016 